\title{
V9 - Avaliação da participação dos componentes vacinais na resposta imune da vacina brasileira contra meningococo $B$ : Perspectivas de otimização da vacina
}

Camila Lordello Xavier ${ }^{1 *}$; Verônica Nascimento Oliveira ${ }^{1}$; Denise da Silva Gomes Pereira ${ }^{1}$; Solange Aparecida Fernandes ${ }^{1}$; Ellen Jessouron ${ }^{1}$.

\section{1 - Bio-Manguinhos/FIOCRUZ}

\section{Introdução:}

A epidemiologia da doença meningocócica apresenta grande variação de acordo com a área geográfica e ao longo do tempo. Os anticorpos desempenham papel central na proteção desta doença, devido a capacidade lítica dos mesmos através da fixação do complemento. BioManguinhos, desde o início dos anos 2000, está envolvido no desenvolvimento da vacina brasileira contra o meningococo B, composta de vesículas de membrana externa (VME) das duas cepas de maior prevalência e LPS detoxificado (dLOS).

\section{Objetivo:}

Verificar o papel dos antígenos vacinais na indução da resposta imune em camundongos a fim de discutir uma potencial otimização da vacina teste.

\section{Metodologia:}

Neste trabalho, foram formuladas seis vacinas experimentais em hidróxido de alumínio: vacina meningocócica $\mathrm{B}$, vacina meningocócica $\mathrm{B}$ combinada à vacina meningocócica $C$ conjugada produzida em BioManguinhos, vacina de VME de N44/89, vacina de VME de N603/95, vacina de VME de N603/95 combinada a VME de N44/89 e vacina de dLOS. Camundongos suíços foram divididos em seis grupos e imunizados com as formulações acima, por via intramuscular, em esquema de três doses com intervalo de 15 dias entre elas. Os anticorpos obtidos a partir do soro dos camundongos vacinados com diferentes preparações tiveram a atividade bactericida avaliada antes e após a adsorção dos soros com os diferentes antígenos vacinais.

\section{Resultados:}

No ensaio bactericida realizado para as duas cepas vacinais, N44/89 e N603/95, todas as preparações testadas induziram soroconversão em título bactericida maior ou igual a quatro vezes em relação aos valores dos soros pré-imunes, 
exceto no grupo que recebeu o dLOS separadamente, que não apresentou resposta protetora. Para todas as vacinas experimentais avaliadas, os títulos bactericidas para N44/89 foram maiores do que para N603/95. Essa indução preferencial de anticorpos para a N44/89 foi confirmada no ensaio de adsorção, no qual foi necessária a utilização de pelo menos três vezes a concentração de proteínas de VME dessa cepa em relação à concentração usada para N603/95. Após a adsorção, as formulações de vesículas separadas apresentaram títulos maiores que as formulações completas e a preparação de dLOS, formulada sem os antígenos protéicos, não apresentou redução de título indicativa de especificidade de anticorpos para esta molécula. No entanto, a combinação de antígenos proteicos com dLOS na adsorção aumentou a redução da queda dos títulos bactericida, principalmente para N44/89.

\section{Conclusão:}

Esses dados sugerem que a indução de resposta protetora da vacina meningocócica B brasileira está relacionada a combinação de antígenos como descrito na literatura. Resultados mais efetivos contra a cepa N603/95 ou outras cepas heterólogas podem ser mais bem avaliados através da mudança das proporções dos antígenos definidos incialmente pela estratégia brasileira. Este trabalho sugere ainda que o LOS tem um papel importante no desempenho da vacina, parecendo contribuir para a indução de anticorpos bactericidas, capazes de aumentar o título protetor.

Palavras-Chave: Vacina meningocócica B, resposta imune, antígenos vacinais 